\title{
ANALISIS DATA SPASIAL MALARIA DI KABUPATEN KULON PROGO TAHUN 2017
}

\author{
Nungki Hapsari Suryaningtyas ${ }^{1^{*}}$, Indah Margarethy ${ }^{1}$, Milana Salim ${ }^{1}$ \\ ${ }^{1}$ Balai Penelitian dan Pengembangan Kesehatan Baturaja \\ JI. A.Yani KM.7 Kemelak Baturaja, Ogan Komering Ulu, 32111 Sumatera Selatan, Indonesia
}

\begin{abstract}
Malaria is one of infectious diseases that is inseparable from the existence of physical and biological environments that support the occurrence of disease. Environmental factors such as climate, temperature and rainfall are factors that trigger reappearance of malaria in a region. The incidence of malaria in DIY Province only occurred in Kulon Progo Regency with the spread in six sub-districts. The purpose of this analysis is to determine the relationship of climate change (rainfall and rainy days) and altitude to the incidence of malaria in Kulon Progo Regency. This study was descriptive using secondary malaria data in Kulon Progo District in 2017. Data on malaria incidence was obtained from the District Health Profile. Kulon Progo, while rainfall, rainy days and altitude data come from the Badan Pusat Statistik. Data was processed and analyzed by overlaying between stratification variables of malaria with variable height, rainfall and rainy days. The results showed that the spatial pattern of malaria occurrences spread throughout the altitude of 500-1000 mdpl, with rainfall $>200 \mathrm{~mm}$ (wet month) and high rainy days. It is necessary to increase awarness by observing rainfall, humidity and temperature on a weekly scale in collaboration with BMKG. It is also recommended to provide counseling to the people in the border areas regarding efforts to prevent malaria transmission.
\end{abstract}

Keywords : Malaria, Kulon Progo, rainfall, altitude

\section{ANALYSIS OF SPATIAL MALARIA IN KULON PROGO REGENCY 2017}

\begin{abstract}
Abstrak
Malaria merupakan salah satu penyakit menular yang tidak terlepas dari keberadaan lingkungan fisik dan biologis yang mendukung terjadinya penyakit. Faktor lingkungan seperti iklim, temperatur dan curah hujan merupakan faktor pemicu pemunculan kembali penyakit malaria di suatu wilayah. Kejadian malaria di Provinsi DIY hanya terjadi di Kabupaten Kulon Progo dengan penyebaran di enam kecamatan. Tujuan analisis ini untuk mengetahui hubungan perubahan iklim (curah hujan dan hari hujan) dan ketinggian tempat terhadap kejadian malaria di Kabupaten Kulon Progo. Kajian ini bersifat deskriptif dengan menggunakan data sekunder malaria di Kabupaten Kulon Progo pada tahun 2017. Data kejadian malaria diperoleh dari Profil Kesehatan Kab. Kulon Progo, sedangkan data curah hujan, hari hujan dan ketinggian tempat berasal dari Badan Pusat Statistik. Data diolah dan dianalisis dengan melakukan overlay antara variabel stratifikasi malaria dengan variabel ketinggian, curah hujan dan hari hujan. Hasil penelitian menunjukkan pola spasial kejadian malaria tersebar di seluruh ketinggian dengan kejadian tertinggi berada di ketinggian 500-1000 mdpl, dengan curah hujan $>200 \mathrm{~mm}$ (bulan basah) dan hari hujan yang tinggi. Perlu dilakukan peningkatan kewaspadaan dengan melakukan pengamatan terhadap curah hujan, kelembapan dan suhu dalam skala mingguan bekerjasama dengan BMKG. Disarankan pula untuk memberikan penyuluhan kepada masyarakat di daerah perbatasan mengenai upaya pencegahan penularan malaria.
\end{abstract}

Kata Kunci : Malaria, Kulon Progo, curah hujan, ketinggian 
*Alamat korespondensi penulis pertama: e-mail: nungkihapsari36@gmail.com; Telp: (0735) 325303

\section{PENDAHULUAN}

Malaria merupakan salah satu masalah kesehatan yang memiliki risiko kematian yang tinggi pada bayi, balita dan ibu hamil. Upaya pemberantasan malaria menjadi salah satu target yang dicanangkan Kementerian Kesehatan dalam program eliminasi malaria pada tahun 2030. Upaya eliminasi dilakukan secara bertahap hingga akhirnya mencakup seluruh wilayah Indonesia. Jumlah kabupaten/kota yang telah mencapai tahap eliminasi malaria hingga tahun 2017 sebanyak 266 kabupaten/kota. ${ }^{1}$

Morbiditas malaria pada suatu wilayah ditentukan dengan Annual Parasite Insidence (API) per tahun. Tren API secara nasional pada tahun 2011 hingga tahun 2015 terus mengalami penurunan. Hal ini menunjukkan keberhasilan program pengendalian malaria yang dilakukan oleh semua pihak terkait. Angka API malaria di Provinsi Daerah Istimewa Yogyakarta (DIY) sebesar 0,03 per 1.000 penduduk pada tahun 2015, dengan tren kasus yang terus menurun dari tahun 2015 sampai dengan 2017 yaitu berturut-turut sebesar 126 kasus, 95 kasus dan 84 kasus. Kejadian malaria di Provinsi DIY hanya terjadi di Kabupaten Kulon Progo dengan penyebaran di enam kecamatan. Kasus terbanyak hanya terjadi di satu kecamatan yaitu Kecamatan Kokap. ${ }^{1}$

Penularan malaria tidak terlepas dari keberadaan lingkungan fisik dan biologis yang mendukung terjadinya penyakit. Faktor lingkungan seperti iklim, temperatur dan curah hujan merupakan faktor pemicu munculnya kembali penyakit malaria di suatu wilayah. Hasil penelitian menyebutkan bahwa curah hujan berpengaruh terhadap fluktuasi vektor di suatu wilayah. Selain itu,

c. k wilayah dengan nilai $\mathrm{API}<1$ permill,

d. Medium case incidence untuk wilayah dengan nilai API 1-<5 permill dan

e. High case incidence untuk wilayah dengan nilai API lebih dari 5 permill.

Klasifikasi ketinggian dibagi menjadi?

a. Dataran rendah (0-100 $\mathrm{mdpl})$,

b. Perbukitan (100-500 mdpl) dan

c. Dataran tinggi (500-1000 mdpl) penyebaran malaria dikatakan dapat terjadi di berbagai wilayah dengan ketinggian yang bervariasi dari 400 sampai dengan 2600 meter di atas permukaan air laut. ${ }^{2}$

Pemberantasan penyakit menular membutuhkan informasi yang berbasiskan lokasi, dimana kejadian penyakit tersebut dapat dipetakan menurut lingkungan sekeliling. Sistem informasi yang mempunyai kemampuan untuk memproses data yang berhubungan dengan lokasi dikenal dengan sebagai sistem informasi geografis (SIG). SIG adalah sistem yang digunakan untuk mengelola data dan informasi keruangan. ${ }^{3}$

Tujuan analisis ini adalah untuk mengetahui hubungan perubahan iklim (curah hujan dan hari hujan) dan ketinggian tempat terhadap kejadian malaria di Kabupaten Kulon Progo secara spasial.

\section{BAHAN DAN METODE}

Kajian ini bersifat deskriptif dengan menggunakan data sekunder malaria di Kabupaten Kulon Progo pada tahun 2017. Data kejadian malaria diperoleh dari profil kesehatan Kabupaten Kulon Progo ${ }^{4}$, sedangkan data curah hujan, hari hujan dan ketinggian tempat berasal dari data Badan Pusat Statistik. ${ }^{5}$ Data diolah dan dianalisis dengan melakukan pemetaan pada setiap variabel yang akan di tumpangsusunkan sehingga menghasilkan beberapa layer hasil tumpang susun tersendiri. Masing-masing variabel yang akan digunakan dilakukan klasifikasi.

Stratifikasi malaria dibedakan berdasarkan nilai API yaitu ${ }^{6}$
a. Noncase untuk wilayah tanpa kasus,
b. Low case incidence untu

Klasifikasi data curah hujan dibedakan menjadi8:

a. Bulan kering $(<100 \mathrm{~mm})$,

b. Bulan lembab (100-200 mm) dan

c. Bulan basah (>200 mm). menjadi ${ }^{\circ}$

Data jumlah hari hujan diklasifikasikan a. Rendah ( $\leq 10$ hari/bulan) dan

b. Tinggi ( $\geq 10$ hari/bulan) 
HASIL

Berdasarkan posisi geografisnya, sebelah Utara Kabupaten Kulon Progo berbatasan dengan Kabupaten Magelang, Provinsi Jawa Tengah. Di sebelah Selatan berbatasan langsung dengan Samudera Hindia. Di sebelah Barat berbatasan dengan Kabupaten Purworejo, Provinsi Jawa Tengah. Di sebelah Timur berbatasan dengan Kabupaten Sleman dan Bantul, Provinsi D.I. Yogyakarta. Kasus malaria tertinggi terkonsentrasi di Kecamatan Kokap, yang berbatasan langsung dengan Kabupaten Purworejo yang merupakan wilayah malaria di Provinsi Jawa Tengah. Lima kecamatan yaitu Samigaluh, Kalibawang, Pengasih, Sentolo dan Wates merupakan wilayah dengan status low case malaria pada tahun 2017 (Gambar 1).

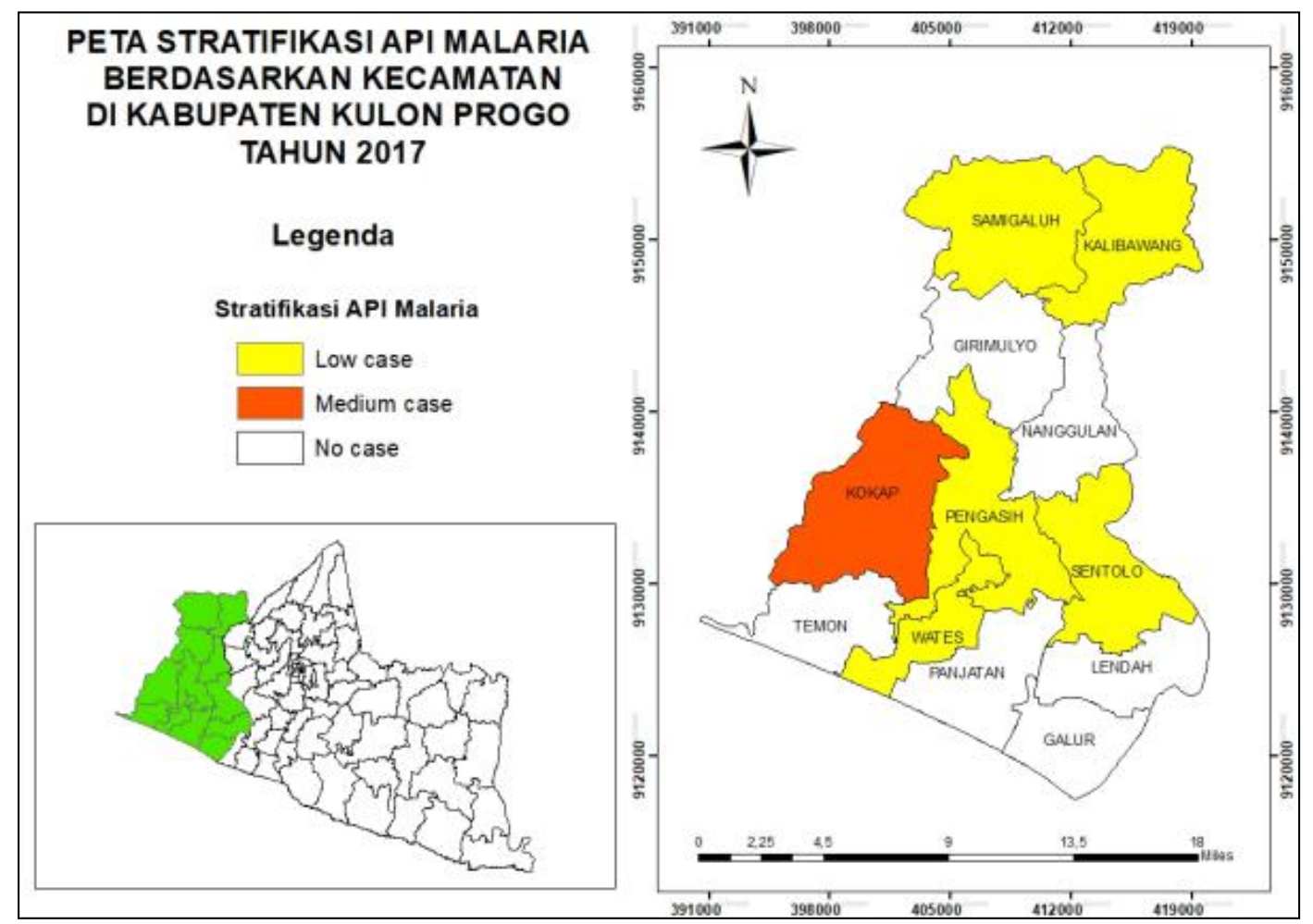

Gambar 1. Peta stratifikasi API malaria berdasarkan kecamatan di Kabupaten Kulon Progo Tahun 2017

Kabupaten Kulon Progo terdiri dari 12 wilayah kecamatan dengan variasi ketinggian atau topografi berkisar antara 100-1000 meter di atas permukaan laut. Bagian Utara merupakan dataran tinggi/perbukitan Menoreh dengan kisaran ketinggian antara 500-1.000 mdpl, meliputi Kecamatan Girimulyo, Nanggulan,
Kalibawang, dan Samigaluh. Bagian tengah merupakan daerah perbukitan dengan ketinggian antara 100-500 mdpl, meliputi Kecamatan Sentolo, Pengasih, dan Kokap. Adapun bagian Selatan merupakan dataran rendah dengan ketinggian 0-100 mdpl, meliputi Kecamatan Temon, Wates, Panjatan, Galur, dan Lendah. 


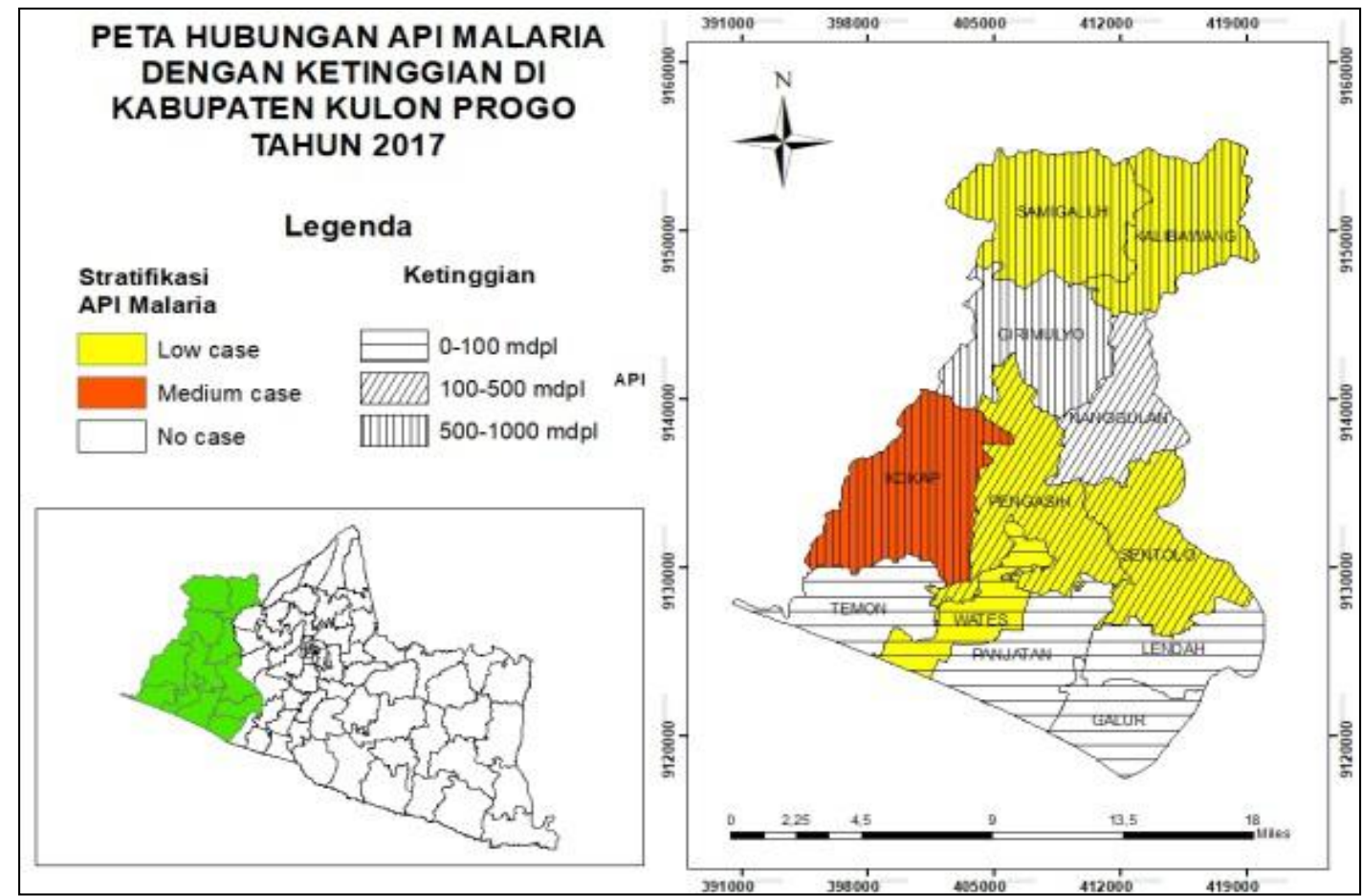

Gambar 2. Peta hubungan API malaria dengan ketinggian berdasarkan Kecamatan di Kabupaten Kulon Progo tahun 2017

Wilayah kecamatan yang berada di bagian Selatan pada kisaran ketinggian di bawah $100 \mathrm{mdpl}$ tergolong sebagai wilayah no case kecuali Kec. Wates yang berbatasan langsung dengan Kec. Pengasih. Wilayah kecamatan pada bagian tengah dengan kisaran ketinggian 100-500 mdpl merupakan wilayah dengan adanya kasus, baik low case (Kec. Sentolo dan Kec. Pengasih) maupun medium case (Kec. Kokap). Pada wilayah dengan kisaran ketinggian lebih dari 500 mdpl ada dua kecamatan yang berstatus low case yakni Kec. Kalibawang dan Samigaluh (Gambar 2).

Berdasarkan data curah hujan, tergambar bahwa curah hujan di Kab. Kulon Progo cukup tinggi. Kecamatan Panjatan, Galuh dan Sentolo tergolong ke dalam wilayah dengan kategori bulan lembap, sedangkan 9 kecamatan lainnya merupakan wilayah dengan kategori bulan basah (Gambar 3). 


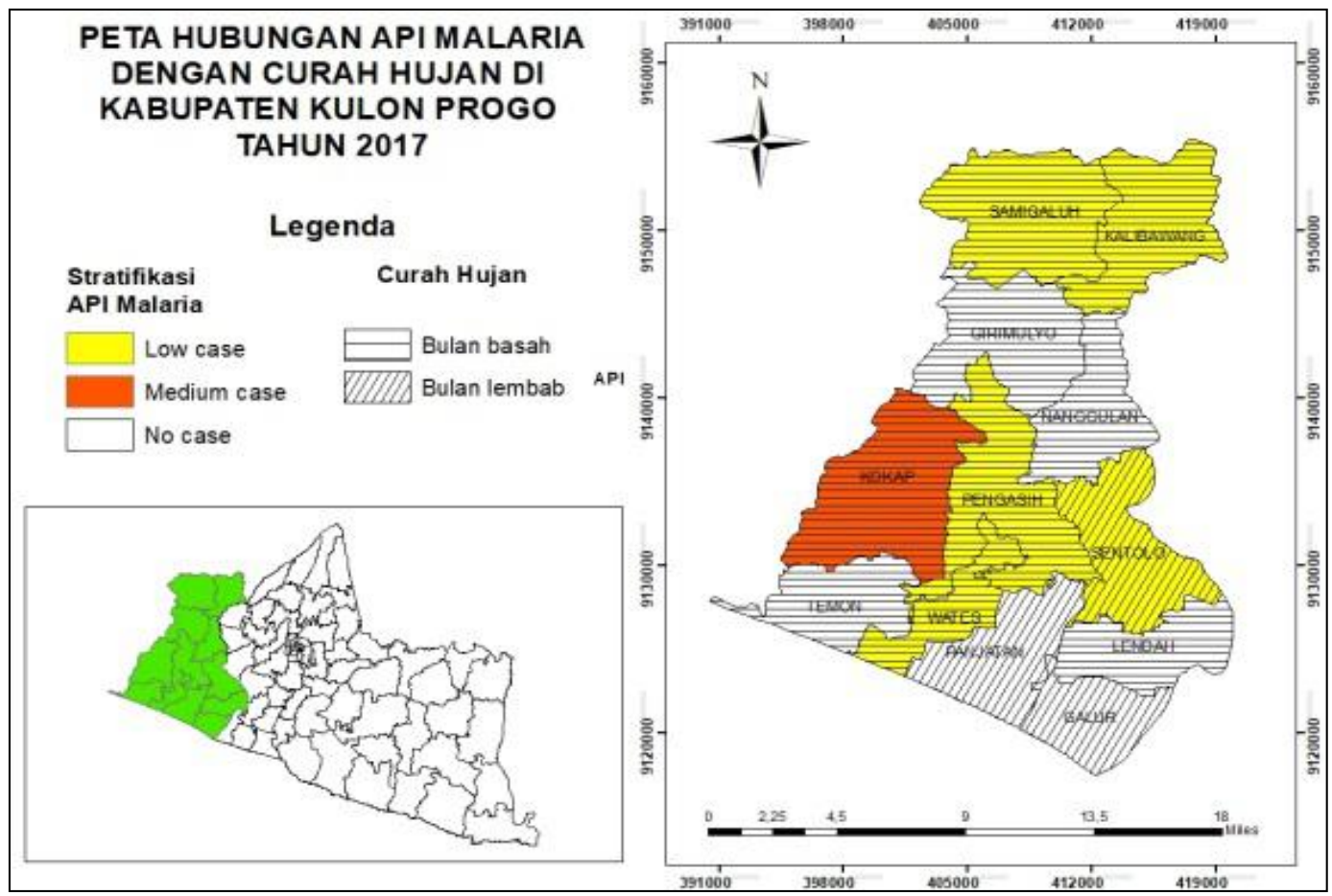

Gambar 3. Peta hubungan API malaria dengan curah hujan berdasarkan Kecamatan di Kabupaten Kulon Progo tahun 2017

Jika dilihat berdasarkan jumlah hari hujan, hampir seluruh kecamatan di Kab. Kulon Progo termasuk dalam kategori sedang dimana jumlah hari hujan per bulan berkisar antara 11-20 hari. Hanya dua kecamatan yang memiliki rata-rata jumlah hari hujan 1-10 hari yakni Girimulyo dan Sentolo.

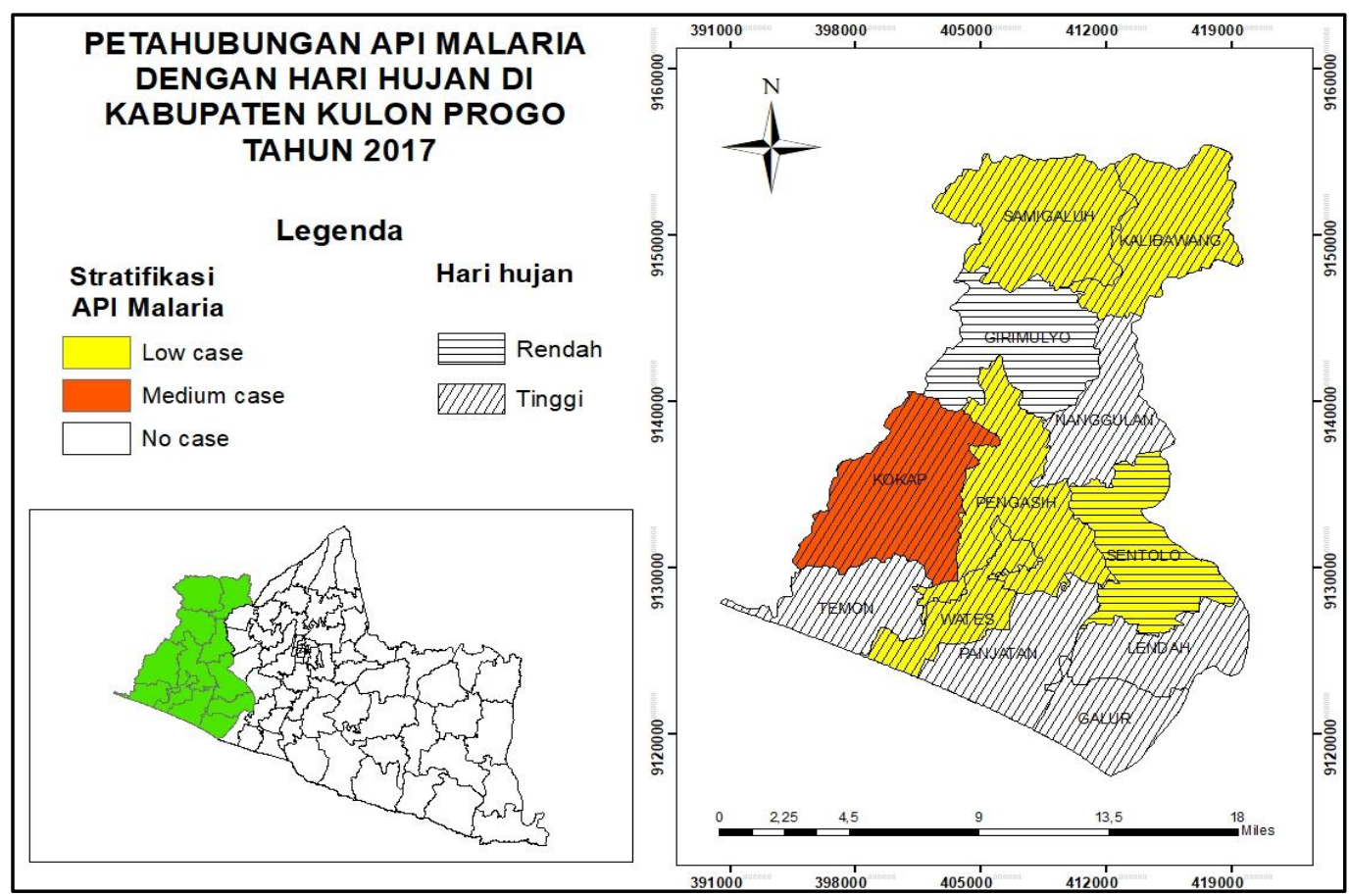

Gambar 4. Peta hubungan API malaria dengan hari hujan berdasarkan Kecamatan di Kabupaten Kulon Progo tahun 2017 


\section{BAHASAN}

Kabupaten Kulon Progo memiliki karakteristik ketinggian wilayah yang bervariasi yang akan mempengaruhi tinggi rendahnya jumlah kasus malaria di wilayah tersebut. Karakteristik ketinggian berhubungan erat dengan keberadaan nyamuk vektor malaria. Nyamuk akan bertahan jika lingkungannya optimal ${ }^{10}$ dan ketinggian merupakan salah satu faktor optimal tersebut.

Rahajo menyatakan bahwa ketinggian optimal bagi nyamuk Anopheles adalah antara 100-130 meter dari permukaan laut. ${ }^{11}$ $\mathrm{Hal}$ ini berbeda dengan hasil analisis yang menunjukkan bahwa kejadian malaria tersebar di seluruh wilayah ketinggian. Wilayah dengan ketinggian 100-500 mdpl di Kabupaten Kulon Progo merupakan perbukitan yang potensial untuk perkembangan nyamuk Anopheles. Hal ini tergambar secara spasial dimana terdapat kasus malaria pada semua kecamatan yang berada di ketinggian ini yakni Kecamatan Kokap dengan status medium case dan dua kecamatan dengan status low case yakni Sentolo dan Pengasih. Pada kondisi optimal perkembangan nyamuk akan cepat, hal ini makin memperbesar kemungkinan kontak dengan manusia sehingga berdampak pada risiko penularan yang semakin besar. ${ }^{12}$

Wilayah bagian utara dan bagian tengah Kab. Kulon Progo merupakan wilayah jajaran Perbukitan Manoreh dengan kondisi topografi berbukit hingga bergunung-gunung Ketinggian wilayah di atas permukaan laut sangat mempengaruhi keberagaman spesies Anopheles. Jajaran Bukit Manoreh merupakan kondisi topografi fisik yang relatif stabil yang mendukung tempat perkembangbiakan nyamuk Anopheles melalui adanya genangan air pegunungan. Kondisi topografi Bukit Manoreh merupakan bebatuan andesits, terdiri dari banyak lembah dan punggung bukit yang membentuk banyak aliran. Kondisi topografi yang kasar dan jenis batuan andesit tersebut menyebabkan daerah ini memiliki porositas rendah yang memungkinkan akumulasi air tergenang pada celah berbatuan, terutama di musim hujan. Kondisi ini mendukung adanya kubangan air yang kondusif sebagai tempat perkembangbiakan vektor malaria. ${ }^{13,14}$
Kecamatan Kokap merupakan satu-satunya kecamatan dengan status medium case. Hasil penelitian Barodji et.al mengungkapkan bahwa Anopheles maculatus dan An. balabacencis dikonfirmasi sebagai vektor malaria di Kecamatan Kokap. ${ }^{14}$ An. maculatus juga dapat ditemukan pada dataran tinggi (500-1000 mdl) seperti yang ditemukan di Kalibawang. ${ }^{15}$ Nyamuk An. maculatus telah dikonfirmasi sebagai vektor malaria di Pulau Jawa maupun Sumatera, nyamuk ini memiliki sebaran ekologis pada daerah perkebunan maupun hutan di kawasan kaki gunung maupun pegunungan. ${ }^{16} \mathrm{Hasil}$ penelitian di Desa Teluk Rendak Kabupaten Sarolangun tempat ditemukannya nyamuk An. maculatus juga dikategorikan sebagai wilayah perbukitan. ${ }^{16} \mathrm{Hasil}$ penelitian Namru juga menjelaskan bahwa spesies $A n$. maculatus telah dikonfirmasi sebagai vektor malaria di jajaran Bukit Manoreh yaitu di Kabupaten Kulon Progo, dan berdasarkan uji ELISA An. vagus positif Plasmodium falcifarum juga dinyatakan sebagai vektor malaria di Kabupaten Kulon Progo. ${ }^{17}$ Hasil konfirmasi ini didukung dengan penelitian yang dilakukan pada tahun 2017 yang menemukan An. vagus terkonfirmasi sebagai vektor di ekosistem non hutan jauh pemukiman. $^{7}$

Selain faktor topografi yang menunjang keberadaan vektor malaria, Kecamatan Kokap merupakan wilayah yang berbatasan langsung dengan Kabupaten Purworejo yang diketahui sebagai wilayah endemis malaria. Kasus malaria sebagian besar terjadi di daerah perbukitan, perbatasan antar kabupaten, dan lebih dekat ke sungai periodik/intermiten. ${ }^{13}$ Situasi ini diperkuat dari hasil distribusi spasial malaria di Purworejo, bahwa sejak tahun 2007 jumlah desa dengan malaria di wilayah Kabupaten Purworejo meningkat dan terkonsentrasi di wilayah timur laut dan timur di perbatasan Magelang dan Kulon Progo. Pada tahun 2010-2011 di Kulon Progo terjadi peningkatan kasus malaria yang tajam dengan satu desa berstatus $\mathrm{HCl}^{14}$ Dataran rendah pada Kabupaten Kulon Progo sebagian besar merupakan wilayah yang non case malaria, hanya Kecamatan Wates yang memiliki kasus dengan status low case. Kecamatan Wates juga berbatasan langsung dengan Kecamatan Pengasih yang 
berstatus low case, sehingga penyebaran malaria dapat terjadi.

Wilayah Kabupaten Kulon Progo yang dikelilingi oleh pegunungan dan perbukitan menyebabkan wilayah ini tidak pernah mengalami musim kering. Curah hujan pada sebagian besar kecamatan berkisar $>200$ $\mathrm{mm}$ per tahun, demikian pula pada wilayah dataran rendah yaitu wilayah bagian selatan. Penelitian Drakeley et al dalam Dwi Sarwani Sri Rejeki ${ }^{11}$, menyatakan adanya korelasi antara ketinggian dan curah hujan dengan kejadian malaria. Ketinggian dapat digunakan untuk menjelaskan transmisi malaria pada suatu wilayah, hanya saja variabel klimatologi tidak bisa berdiri sendiri untuk menjelaskan kejadian malaria. Tinggi rendahnya curah hujan akan mempengaruhi keberadaan habitat perkembangan vektor malaria. Curah hujan yang tinggi dapat meningkatkan jumlah genangan air yang berpotensi menjadi habitat perkembangbiakan nyamuk vektor malaria. Adanya hujan akan menambah jumlah dan jenis genangan air. Hal ini juga didukung oleh kondisi topografi dataran tinggi Kabupaten Kulon Progo yang banyak cerukan/kubangan pada celah bebatuan. Hujan juga dapat meningkatkan kelembapan relatif, sehingga memperpanjang usia nyamuk dewasa. ${ }^{18}$ Curah hujan minimum yang dibutuhkan oleh nyamuk untuk berkembang adalah $1,5 \mathrm{~mm}$ perhari. ${ }^{19}$ kelembapan yang tinggi juga mempengaruhi nyamuk menjadi lebih aktif dan sering menggigit, sehingga meningkatkan penularan malaria. kelembapan yang rendah memperpendek umur nyamuk, meskipun tidak berpengaruh pada parasit. ${ }^{19}$

Jumlah hari hujan di Kabupaten Kulon Progo yang berkisar 11-20 hari menunjukkan bahwa terdapat jeda pada setiap turun hujan sehingga saat genangan air terbentuk nyamuk dapat memulai siklus hidupnya dengan kondisi lingkungan yang mendukung. Hujan menyediakan banyak keuntungan bagi nyamuk untuk berkembang biak akan tetapi hujan deras yang terus menerus dapat merusak tempat perkembangbiakan nyamuk dan menyebabkan turunnya populasi nyamuk. ${ }^{11,19} \mathrm{Hal}$ ini sejalan dengan penelitian di Kota Bengkulu bahwa ada hubungan bersifat negatif yang berarti apabila jumlah hari hujan meningkat akan diikuti dengan penurunan kasus malaria. ${ }^{20}$ Pada umumnya hujan yang diselingi panas akan mempermudah perkembangan nyamuk dan terjadinya epidemik malaria.

Faktor lingkungan umumnya sangat dominan sebagai penentu kejadian malaria, nyamuk dapat berkembang biak bila keadaan lingkungannya mendukung. Vegetasi alami yang terdapat di Kabupaten Kulon Progo sebagian besar terdiri dari hutan, kebun campuran, lahan pertanian, dan semak-semak baik di daerah dataran tinggi dan rendah ${ }^{14}$ juga berpotensi memungkinkan menjaga suhu dan kelembapan yang dapat mempertahankan lingkungan yang ideal sebagai tempat perkembangbiakan vektor malaria.

Berdasarkan penelitian yang dilakukan oleh Ricota et al, didapatkan hasil bahwa keberadaan vegetasi di sekitar pemukiman berperan dalam mempengaruhi perilaku nyamuk, kebiasaan mencari makan, dan akan berpengaruh pula pada kejadian malaria berikutnya. ${ }^{21}$ Kondisi ini merupakan habitat yang disenangi An. maculatus, dimana habitat stadium larva biasanya di sungai kecil/mata air dengan air jernih di pegunungan yang kena sinar matahari langsung, lebih senang yang ada tanaman air. Hasil penelitian bionomik An. maculatus di areal kebun kopi milik masyarakat di kawasan perbukitan Kecamatan Kisam Tinggi Kabupaten Ogan Komering Ulu Selatan menunjukkan bahwa An. maculatus lebih banyak tertangkap pada musim penghujan. ${ }^{22}$

Hasil penelitian lainnya menyebutkan bahwa An. vagus lebih menyukai berkembang biak pada air yang tidak mengalir, sedangkan di daerah Jawa Tengah Anopheles jenis ini ditemukan di habitat sawah, rawa, tambak, genangan air pada batu sungai, dan genangan luapan sungai. ${ }^{23}$

\section{KESIMPULAN}

Pola spasial kejadian malaria di Kabupaten Kulonprogo tersebar di ketinggian 0-100 mdpl, 100- $500 \mathrm{mdpl}$ maupun 500-1000 mdpl. Angka kejadian tertinggi berada di ketinggian 500-1000 mdpl, dengan curah hujan pada kondisi bulan basah dan hari hujan yang tinggi. 


\section{SARAN}

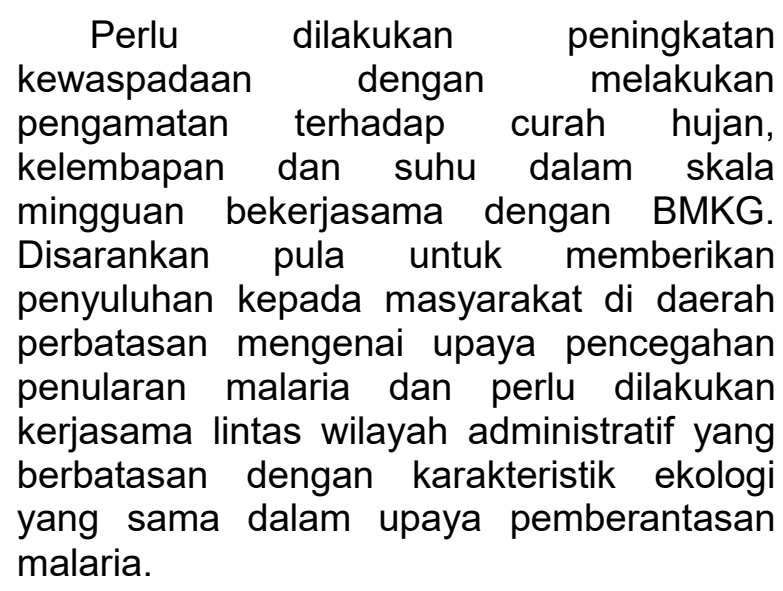

\section{KONTRIBUSI PENULIS}

Kontribusi penulis pada artikel ini yaitu, kontributor utama adalah NHS, IM dan MS.

\section{UCAPAN TERIMA KASIH}

Penulis mengucapkan terima kasih kepada Kepala Balai Litbangkes Baturaja yang telah mendukung dan memberikan kesempatan kepada penulis untuk menyelesaikan tulisan ini.

\section{DAFTAR PUSTAKA}

1. Pusat Data dan Informasi Kementerian Kesehatan RI. Malaria. Jakarta; 2016.

2. Sutarto, B EC. Faktor Lingkungan, Perilaku dan Penyakit Malaria. J Agromed Unila. 2017;4(1):173-184.

3. Izza N dan S. Analisis Data Spasial Penyakit Difteri di Provinsi Jawa Timur Tahun 2010 dan 2011. Bul Penelit Sist Kesehat. 2015;18(2):211-219.

4. Dinas Kesehatan Kabupaten Kulonprogo. Profil Kesehatan tahun 2018 (Data 2017) Kulonprogo.; 2018.

5. Badan Pusat Statistik Kabupaten Kulon Progo. Kabupaten Kulon Progo dalam Angka 2018.; 2018.

6. Kementerian Kesehatan RI. Keputusan Menteri Kesehatan Republik Indonesia Tentang Pedoman Surveilans Malaria.; 2007:1-60.

7. Badan Penelitian dan Pengembangan
Kesehatan Kementerian Kesehatan RI. Laporan Akhir Riset Khusus Vektor dan Reservoir Penyakit Provinsi Daerah Istimewa Yogyakarta Tahun 2017.; 2017.

8. Dewi Handayani Untari Ningsih. Metode Thiessen Polygon untuk Ramalan Sebaran Curah Hujan Periode Tertentu pada Wilayah yang Tidak Memiliki Data Curah Hujan. J Teknol Inf Din. 2012; Volume 17(No 2):154-163.

9. Asnifatima A. Pola Kecenderungan Spasial Kejadian Malaria (Studi Kasus; di Kabupaten Kepulauan Selayar Tahun 2011 - 2013). Hear J Kesehat Masy. 2017;5(1):1-12. http://ejournal.uika-bogor.ac.id/index. php/Hearty/article/view/1051/865.

10. Elyazar IRF, Sinka ME, Gething PW, Tarmidzi SN, Surya A, Kusriastuti R. The Distribution and Bionomics of Anopheles Malaria Vector Mosquitoes in Indonesia. Adv Parasitol. 2013;83:173-266.

doi:10.1016/B978-0-12-4077058.000 03-3

11. Rejeki DSS, Sari RA, Nurhayati N. Annual Parasite Incidence Malaria di Kabupaten Banyumas. J Kesehat Masy Nas. 2014;9(2):137-143.

12. Tian $\mathrm{H}, \mathrm{Bi} P$, Cazelles $\mathrm{B}$, et al. How environmental conditions impact mosquito ecology and Japanese encephalitis: An eco-epidemiological approach. Environ Int. 2015;79:17-24. doi:10.1016/j.envint.2015.03.002

13. Murhandarwati EEH, Fuad A, Wijayanti MA, et al. Change of Strategy is Required for Malaria Elimination: A Case Study in Purworejo District, Central Java Province, Indonesia. Malar J. 2015;14(318):1-14. doi:10.1186/s12936-015-0828-7

14. Murhandarwati EEH, Fuad $A$, Nugraheni MDF, Wijayanti MA, Widartono BS, Chuang T. Early malaria resurgence in pre-elimination areas in Kokap Subdistrict, Kulon Progo , Indonesia. Malar $\mathrm{J}$. 2014;13(130):1-15. 
15. Windarso SE, Rubaya AK, Suwerda B Ganefati SP. Studi Bionomik Vektor Malaria di Kecamatan Kalibawang, Kulonprogo. JRL. 2008;4(2):111-117.

16. Taviv $Y$, Budiyanto $A$, Sitorus $H$, Ambarita LP, Mayasari R, Pahlepi RI. Sebaran Nyamuk Anopheles Pada Topografi Wilayah yang Berbeda di Provinsi Jambi. Media Penelit dan Pengemb. 2015;25(2):1-8.

17. R.A.Wigati, Mardiana, Mujiyono, Siti Alfiah. Deteksi Protein Circum Sporozoite Pada Spesies Nyamuk Anopheles Vagus Tersangka Vektor Malaria di Kecamatan Kokap, Kabupaten Kulon Progo dengan Uji ELISA. Media Litbang Kesehat. 2010;20(3):118-123.

18. Solikhah. Identifikasi Vektor Malaria. $J$ Kesehat Masy

Nas. 2013;7(9):402-407.

19. Mardiana, Musadad DA. Pengaruh Perubahan Iklim Terhadap Insiden Malaria di Kabupaten Bintan Kepulauan Riau dan Kabupaten Banggai Sulawesi Tengah. J Ekol
Kesehat. 2012;11(1):52-62.

20. Gustina M, Jubaidi. Studi Ekologi Hubungan Iklim Dengan Kejadian Malaria di Kota Bengkulu Tahun 2011-2013. J Media Kesehat. 2015;8(1):58-62.

21. Ricotta EE, Frese SA, Choobwe C, Louis TA, Shiff CJ. Evaluating local vegetation cover as a risk factor for malaria transmission: a new analytical approach using ImageJ. Malar J. 2014;13(94):1-7.

22. Ambarita LP, Taviv Y, Purnama D, Betriyon, Pahlepi RI, Saikhu A. Beberapa Aspek Bionomik Anopheles Maculatus dan An. Leucosphyrus di Perkebunan Kopi Daerah Endemis Malaria Kabupaten OKU Selatan. J Ekol Kesehat. 2011;10(4):229-238.

23. Astuti EP, Ipa M, Prasetyowati $H$, Fuadzy $\mathrm{H}$, Dhewantara PW. Kapasitas vektor dan laju inokulasi entomologis Anopheles vagus dari wilayah endemis malaria di Provinsi Banten. vektora. 2016;8(1):23-30. 